\title{
SCREENING A COLLECTION OF COTTON GENOTYPES FOR FUSARIUM WILT RESISTANCE UNDER GREENHOUSE CONDITIONS IN 2017
}

\author{
ASRAN. AMAL A., M.T.M. MANSOUR, M.S. KHALIL, A.Z.A. ASHOUR, \\ S.M.E. ZAYED, MARIAN M. HABEB and A.A. ALY
}

Plant Pathol. Res. Instit., ARC, Giza, Egypt

(Manuscript received 13 March 2018)

\begin{abstract}
$\mathrm{T}$ he genotypes evaluated in this study was a part of the National Screening Program for Fusarium Wilt Resistance. This program is conducted annually in the greenhouses of Cotton and Fiber Crops Diseases Research Dept., PPRI. The present study included 50 of Upper Egypt experimental genotypes and 875 families of six commercial cultivars. The experimental genotypes were supplied by Cotton Breeding Dept., and the six commercial cultivars were provided by Cotton Maintenance Dept., Cotton Research Institute. Healthy survival rate of seedlings of the genotypes was used as a criterion to evaluate the reactions when the genotypes were grown in autoclaved highly infested soil with a mixture of race 3 of Fusarium oxysporum f.sp. vasinfectum isolates. The majority of the tested genotypes (48\%) were very highly resistant while $22 \%$ were very highly susceptible. All the families of the commercial cultivars Giza 90, Giza 95, Giza 86, Giza 87, and Giza 88 were very highly resistant while only $99.30 \%$ of Giza 92 families showed this level of resistance, which deserves more attention in monitoring its families in the future to Avoid any varietal deterioration. The present work provides new and useful sources of resistance to FOV race 3 isolates.
\end{abstract}

\section{INTRODUCTION}

Fusarium wilt of cotton is a serious fungal disease responsible for significant losses throughout the world.The causal organism Fusarium oxysporum Schlecht.f.sp. vasinfectum (ATK) Snyd and Hans (FOV), invades the host through the taproots behind the root tip. The combined effect of fungal metabolites and the production of lipodial substances by the host in response to infection may lead to occlusion of the vascular tissue, resulting in wilt of the cotton plant (Hillocks,1984). The pathogen can survive for several decades in soil and cannot be eradicated from infested fields. The pathogen can infect cotton at all stages of growth and produces symptoms, which include seedling death, wilting, vascular discoloration and plant death (Watkins,1981). Apart from, Egypt, it is commonly associated with nematode infection [root knotFusarium wilt complex (McFadden et al., 2004)], particularly in acidic, sandy soils. In Egypt, where cotton is grown in alkaline clay soils, there is no evidence for the involvement of nematodes in Fusarium wilt disease (Aly et al., 2000). 
Currently, up to eight races of (FOV), most of which are geographically separated, are recognized worldwide. The basis for determining races of FOV depends on their virulence to a differential set of cotton(Gossypium) lines and species and up to 5 non- cotton hosts (Watkins,1981).

The Egyptian race (race 3) of FOV has long been known in the Nile Valley, where it remains one of the most damaging pathogen on Egyptian cottons (Gossypium brbadense L.). This race also attacks G.brbadense in the former Soviet Union(Watkins,1981). and Israel (Netzer et al, 1985).

FOV caused serious losses in the commercial Egyptian. Cottons (G.brbadense L.) in the late fifties (Barky et al.,1958). Since then, extensive cotton breeding programs were conducted to develop cultivars resistant to the disease.

Breeding materials submitted by cotton breeders (Cotton Research Institute) have been screened for resistance under greenhouse conditions in soil highly infested with FOV. This test has been conducted annually for the past 65 years in the greenhouses of Cotton and Fiber Crops Diseases Research Dept, PPRI, ARC. The program has been successful enough in developing highly resistant cultivars. (Aly et al, 2000).

Fusarium wilt remains a potential threat to cotton production in Egypt because FOV is still well established in the Egyptain soil (Aly et al, 2000) Thus, increasing the probability that new races other than race 3 or new biotypes of this race may arise to confound cotton breeders.

The objective of the present study was to evaluate a collection of cotton germplasm against Fusarium wilt race 3 under greenhouse conditions by using families of experimental genotypes and commercial cultivars.

\section{MATERIALS AND METHODS}

\section{Cotton germplasm}

The germplasm used in this study included 50 of Upper Egypt experimental genotypes (Table 1) were supplied by Cotton Breeding Section, as well as 875 families of six commercial cultivars (Table 4) were supplied by Cotton Maintenance Section, Cotton Research Institute.

\section{Evaluation of cotton germplasm against Fusarium wilt race 3 under greenhouse conditions.}

This study was conducted in the greenhouses of Cotton and Fiber Crops Diseases Research Dept, PPRI through 2017.The experimental design used in this study was a completely randomized with three replications (pots) for each genotype.

The fungal inoculum used in the greenhouse test was a mixture of equal parts (w/w) of 50 isolates of FOV race 3 . These isolates were obtained from the fungal collection 
of Cotton Pathology Dept, PPRI, Giza. Autoclaved clay loam soil was infested with a mixture of the isolates at a rate of $10 \mathrm{~g} / \mathrm{kg}$ soil, prepared in $500-\mathrm{ml}$ glass bottles, each bottle contained $50 \mathrm{~g}$ of sorghum grains and $40 \mathrm{ml}$ of tap water. The inocula made from one- week old culture on PDA, were allowed to colonize sorghum for 3 weeks. Infested soil was dispensed in 10-cm diameter clay pots, which were planted with 10 seeds per pot..The greenhouse was equipped with a heating system assuring that the minimum temperature in the greenhouse was maintained at $28^{\circ} \mathrm{c}$; however,due to the lack of cooling system, the maximum temperature was out of control fluctuating from 30 to $35{ }^{\circ} \mathrm{C}$ depending on the prevailing temperature during the day ( the test was conducted in January and February, 2017).

\section{Assessment of Fusarium wilt incidence}

Percentages of infected seedlings were recorded 45 days from planting date. The infected seedlings included the dead and the surviving seedling, which showed external or internal symptoms. The external symptoms usually began at the margin of cotyledons as yellowing along the veins (vein clearing), eventually, the entire cotyledonds turned yellow and dropped from the seedlings. Seedlings that remained apparently healthy 45 days after planting were cut diagonally across the root and stem to examine the internal symptoms. If discoloration of xylem vessels was observed, they were considered infected. If seedlings were free of such a discoloration, they were considered healthy. Thus, the seedlings of each genotype were placed in two distinct classes: healthy if they were free of any external or internal symptoms,or infected if the seedlings died or survived showing any external or internal symptoms. ( Aly et al.,2007 and Abd-Elsalam et al., 2009).

\section{RESULTS}

Seedlings within each of the tested genotypes showed variable symptoms expression (Table 1) due to the fact that many of these genotypes were not pure lines.

Healthy survival rate was used as a criterion to evaluate the reactions of the tested genotypes to Fusarium wilt (Table 2). The majority of the tested genotypes (48 $\%$ ) were VHR while $22 \%$ were VHS. The other reaction classes ranged from 2 to 16 $\%$ of the tested genotypes (Table 3 ).

All the families of the commercial cultivars Giza 90, Giza 95, Giza 86, Giza 87, and Giza 88 were VHR while only $99.30 \%$ of Giza 92 families showed this high leve of resistance (Table 4). 
Table 1. Symptoms of Fusarium wilt disease of a random collection of Upper Egypt Cotton genotypes when they tested under greenhouse conditions in 2017.

\begin{tabular}{|c|c|c|c|}
\hline \multirow[b]{2}{*}{ Gnoetype ${ }^{\mathrm{b}}$ no. } & \multicolumn{3}{|c|}{ Symptoms ${ }^{a}(\%)$} \\
\hline & VD & CY & DS \\
\hline 1 & 4.54 & 0.00 & 95.46 \\
\hline 8 & 17.39 & 0.00 & 73.91 \\
\hline 18 & 9.52 & 0.00 & 90.47 \\
\hline 29 & 4.17 & 0.00 & 95.80 \\
\hline 30 & 0.00 & 0.00 & 100.00 \\
\hline 42 & 0.00 & 0.00 & 100.00 \\
\hline 50 & 0.00 & 11.53 & 57.69 \\
\hline 58 & 10.53 & 0.00 & 89.47 \\
\hline 59 & 0.00 & 0.00 & 100.00 \\
\hline 66 & 0.00 & 0.00 & 100.00 \\
\hline 77 & 0.00 & 0.00 & 0.00 \\
\hline 86 & 0.00 & 0.00 & 0.00 \\
\hline 88 & 0.00 & 0.00 & 0.00 \\
\hline 97 & 0.00 & 3.84 & 0.00 \\
\hline 105 & 0.00 & 0.00 & 10.00 \\
\hline 114 & 0.00 & 0.00 & 0.00 \\
\hline 117 & 0.00 & 0.00 & 0.00 \\
\hline 129 & 0.00 & 0.00 & 0.00 \\
\hline 136 & 0.00 & 0.00 & 0.00 \\
\hline 142 & 0.00 & 0.00 & 0.00 \\
\hline 151 & 0.00 & 0.00 & 0.00 \\
\hline 163 & 0.00 & 0.00 & 0.00 \\
\hline 170 & 0.00 & 4.00 & 0.00 \\
\hline 176 & 0.00 & 0.00 & 0.00 \\
\hline 179 & 0.00 & 0.00 & 0.00 \\
\hline 187 & 0.00 & 0.00 & 0.00 \\
\hline 196 & 0.00 & 0.00 & 0.00 \\
\hline 206 & 0.00 & 0.00 & 0.00 \\
\hline 211 & 7.69 & 0.00 & 0.00 \\
\hline 219 & 0.00 & 0.00 & 0.00 \\
\hline 229 & 0.00 & 0.00 & 0.00 \\
\hline 239 & 0.00 & 0.00 & 0.00 \\
\hline 240 & 0.00 & 0.00 & 0.00 \\
\hline 247 & 0.00 & 0.00 & 0.00 \\
\hline 252 & 0.00 & 0.00 & 0.00 \\
\hline 260 & 0.00 & 20.00 & 30.00 \\
\hline 270 & 0.00 & 52.94 & 11.76 \\
\hline 271 & 0.00 & 57.89 & 31.50 \\
\hline 281 & 0.00 & 27.27 & 9.09 \\
\hline 285 & 10.52 & 42.10 & 15.78 \\
\hline
\end{tabular}


Table 1. cont.

\begin{tabular}{|c|ccc|}
\hline \multirow{2}{*}{ Gnoetype $^{\text {b }}$ no. } & \multicolumn{3}{|c|}{ Symptoms $^{\mathbf{a}} \mathbf{( \% )}$} \\
\cline { 2 - 4 } 289 & VD & CY & DS \\
298 & 0.00 & 18.18 & 31.81 \\
300 & 0.00 & 0.00 & 53.33 \\
309 & 3.84 & 0.00 & 42.30 \\
313 & 0.00 & 60.00 & 0.00 \\
321 & 0.00 & 0.00 & 100.00 \\
328 & 4.76 & 0.00 & 80.90 \\
329 & 0.00 & 0.00 & 100.00 \\
334 & 0.00 & 0.00 & 83.35 \\
341 & 0.00 & 15.78 & 42.1 \\
& 5.88 & 0.00 & 76.47 \\
\hline
\end{tabular}

Symptoms ${ }^{\mathrm{a}}$ were Vascular discoloration (VD ), Cotyledonary yellowing (CY) and Dead seedlings ( DS ).

beach genotype was represented by 20 to 25 seedlings.

Table 2. Reaction classes of a random collection of Upper Egypt Cotton genotypes to Fusarium wilt disease based on the percentage of healthy survival(HS)

\begin{tabular}{|c|c|c|}
\hline Gnoetype no. & HS (\%) & Reaction class $^{\mathrm{a}}$ \\
\hline 1 & 0.00 & VHS \\
\hline 8 & 8.69 & VHS \\
\hline 18 & 0.00 & VHS \\
\hline 29 & 0.00 & VHS \\
\hline 30 & 0.00 & VHS \\
\hline 42 & 0.00 & VHS \\
\hline 50 & 30.77 & $\mathrm{~S}$ \\
\hline 58 & 0.00 & VHS \\
\hline 59 & 0.00 & VHS \\
\hline 66 & 0.00 & VHS \\
\hline 77 & 100.00 & VHR \\
\hline 86 & 100.00 & VHR \\
\hline 88 & 100.00 & VHR \\
\hline 97 & 96.16 & VHR \\
\hline 105 & 90.00 & $\mathrm{HR}$ \\
\hline 114 & 100.00 & VHR \\
\hline 117 & 100.00 & VHR \\
\hline 129 & 100.00 & VHR \\
\hline 136 & 100.00 & VHR \\
\hline 142 & 100.00 & VHR \\
\hline 151 & 100.00 & VHR \\
\hline 163 & 100.00 & VHR \\
\hline 170 & 96.00 & VHR \\
\hline 176 & 100.00 & VHR \\
\hline 179 & 100.00 & VHR \\
\hline 187 & 100.00 & VHR \\
\hline 196 & 100.00 & VHR \\
\hline 206 & 100.00 & VHR \\
\hline 211 & 92.31 & VHR \\
\hline 219 & 100.00 & VHR \\
\hline 229 & 100.00 & VHR \\
\hline 239 & 100.00 & VHR \\
\hline 240 & 100.00 & VHR \\
\hline 247 & 100.00 & VHR \\
\hline 252 & 100.00 & VHR \\
\hline 260 & 50.00 & $\mathrm{~S}$ \\
\hline 270 & 35.29 & $\mathrm{~S}$ \\
\hline 271 & 10.60 & HS \\
\hline 281 & 63.63 & $\mathrm{R}$ \\
\hline 285 & 31.57 & $\mathrm{~S}$ \\
\hline
\end{tabular}


Table 2. cont.

\begin{tabular}{|c|c|c|}
\hline Gnoetype no. & HS ( \%) & Reaction class ${ }^{\mathrm{a}}$ \\
\hline 289 & 50.00 & $\mathrm{~S}$ \\
\hline 298 & 46.66 & S \\
\hline 300 & 53.84 & $\mathrm{R}$ \\
\hline 309 & 40.00 & S \\
\hline 313 & 0.00 & VHS \\
\hline 321 & 14.34 & $\mathrm{HS}$ \\
\hline 328 & 0.00 & VHS \\
\hline 329 & 17.65 & $\mathrm{HS}$ \\
\hline 334 & 42.11 & S \\
\hline 341 & 17.64 & HS \\
\hline
\end{tabular}

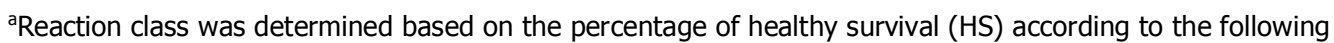
scale:-

Very highly susceptible (VHS) $=0-10$

highly susceptible $(\mathrm{HS})=11-30$

Susceptible $(\mathrm{S})=31-50$

Resistant $(R)=51-70$

Highly resistant $(H R)=71-90$

Very Highly resistant $(\mathrm{V} \mathrm{H} \mathrm{R})=91-100$

Table 3. Distribution of a random collection of Upper Egypt cotton genotypes based on their reaction classes to Fusarium wilt disease.

\begin{tabular}{|l|cc|}
\hline & \multicolumn{2}{|c|}{ Genotypes } \\
\cline { 2 - 3 } Reaction class $^{\mathbf{a}}$ & No & \% \\
\hline VHS & 11 & 22 \\
HS & 4 & 8 \\
S & 8 & 16 \\
R & 2 & 4 \\
HR & 1 & 2 \\
VHR & 24 & 48 \\
Total & 50 & 100 \\
\hline
\end{tabular}

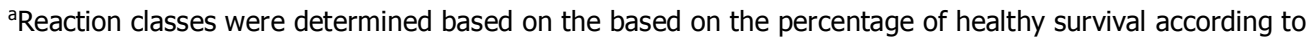
the scale shown in Table2.

Table 4. Distribution of commercial cotton cultivars supplied by Cotton Maintenace Section, Cotton Research Institute based on their reaction classes to Fusarium wilt disease.

\begin{tabular}{|c|c|c|c|c|c|c|c|}
\hline \multirow[b]{2}{*}{ Cultivar } & \multirow[b]{2}{*}{$\begin{array}{l}\text { Total no. of } \\
\text { tested families }\end{array}$} & \multicolumn{3}{|c|}{ Reaction } & \multirow{2}{*}{$\begin{array}{c}\text { class }^{\mathrm{a}} \\
\mathbf{R}\end{array}$} & \multicolumn{2}{|l|}{$(\%)$} \\
\hline & & VHS & HS & $\mathbf{S}$ & & HR & VHR \\
\hline Giza 90 & 155 & 0.00 & 0.00 & 0.00 & 0.00 & 0.00 & 100.00 \\
\hline Giza 92 & 138 & 0.00 & 0.00 & 0.00 & 0.00 & 0.70 & 99.30 \\
\hline Giza 95 & 151 & 0.00 & 0.00 & 0.00 & 0.00 & 0.00 & 100.00 \\
\hline Giza 86 & 156 & 0.00 & 0.00 & 0.00 & 0.00 & 0.00 & 100.00 \\
\hline Giza 87 & 123 & 0.00 & 0.00 & 0.00 & 0.00 & 0.00 & 100.00 \\
\hline Giza 88 & 152 & 0.00 & 0.00 & 0.00 & 0.00 & 0.00 & 100.00 \\
\hline
\end{tabular}

${ }^{\text {aReaction }}$ classes were determined based on the percentage of healthy survival according to the scale showen in Table 2. 


\section{DISCUSSION}

In the present study, genotypes were screened against 50 FOV isolates collected from almost all cotton growing areas in Egypt. The use of such a large number of isolates is a strategy to maximize the probability that resistant genotypes identified under greenhouse conditions will maintain their resistance levels under field conditions in distinct geographic locations. On the contrary, if genotypes were screened against a limited number of isolates, they may not perform as expected due to potential presence of isolates differing in their virulence profile from those used in the greenhouse test.

A distinctive characteristic of Fusarium wilt is the olive brown discoloration of the root and stem xylem. However, there is no consensus regarding the diagnostic importance of this vascular discoloration for evaluation of the host germplasm reaction to Fusarium wilt. For example, Armstrong and Armstrong (1978) stated that vascular discoloration is a questionable standard for judging susceptibility to wilt in seedling tests. Zink et al. (1983) found no clear relationship between the severity of external symptoms in surviving muskmelon seedlings and the extent and degree of internal vascular discoloration. On the other hand, salgado et al. (1994) used vascular discoloration as a criterion for judging susceptibility of tepary bean (phaseoulus acutifolius Gray) seedlings to Fusarium wilt. Osman (1996) found a highly significant correlation ( $r=0.98, p \leq 0.01)$ between external wilt symptoms and vascular discoloration of cotton seedlings (cultivar Giza74). In the present study, we used more rigorous criteria for disease rating. According to these criteria, the seedlings were considered slightly susceptible if they showed internal discoloration even though they were free of external symptoms. Thus, the seedlings were considered resistant only if they were completely free of any internal and external symptoms. In our study, cotton genotypes were screened under very favorable conditions for FOV development. The soil was sterile, temperature was optimal most of the time, and the inoculum density was relatively high. Under these conditions, it is unlikely that any susceptible genotypes would have escaped from infection. However, one should keep in mind that evaluation in the greenhouse precludes identifying genotypes that may possess useful levels of field resistance to wilt. The soil infestation method, which we used for seedling inoculation, had several advantages. Assays were simple, did not damage the seedlings and provided discriminating and reproducible disease reactions. Since no cotton wilt nurseries have been established in Egypt, greenhouse tests will continue to be the only reliable method for screening cotton breeding materials for Fusarium wilt resistance. The current absence of Fusarium wilt in commercial cotton field using cultivars derived from our testing program demonstrates the reliability of these screening procedures, which we have adopted in testing cotton genotypes for Fusarium -wilt resistance. The most successful strategy to manage Fusarium wilt is the use of resistant cultivars (Doan and Davis,2014). Therefore the present work provides new and useful sources of resistance that might be employed in breeding programs aiming to develop cotton cultivars with resistance to FOV race 3 isolates. However, one should keep in mind that Giza 92 families deserve more any varietal detewrioration. 


\section{REFERENCES}

1. Abd-Elsalam, K.A., M.R. Omar, Amal A.Asran, and A.A.Al 2009. Differential Interactions among cotton genotypes and isolates of Fusariu oxysporum Schlecht.f.sp. vasinfectum . Archives of Phytopathology and Plant Protection 42:464-473.

2. Aly, A.A.,E.M.Hussin, M.R.Oma,r and A.M.A.El-Samawaty.2007. Use of Protein electrophoresis to quantify resistance of cotton to Fusarium wilt disease. J.Agric.Sci. Mansoura Univ.32:3475-3488.

3. Aly, A.A., H.A. Eisa, M.T.M. Mansour, S.M.E. Zayed, and M.R. Omar. 2000. Resistance to. Fusarium wilt disease in families of some commercial cotton cultivars. In the $19^{\text {th }}$ Conf. of the Egyptian Phytopathological Society, 3- 4 May 2000, Giza , Egypt.pp.113-121.

4. Armstrong, G.M. and J.k. Armstrong.1978. Formae speciales and races of Fusarium oxysporum causing wilts of the Cucurbitacease. Phytopathology 68: $19-28$.

5. Bakry,M.A,A.H.Sakre, O.A.Kassab, and R.H.Rizk.1958.infection of some Cotton varieties with Fusarium and possibility of the existence of Strains of thefungus. In Proc.the $2^{\text {nd }}$ Cotton Conf.(in Arabic).Giza,Egypt.

6. Doan,H.K.and R.M.Davis.2014. Evaluation of Fusarium wilt resistance in six upland cotton germplasm lines. The Journal of Cotton Science 18:430-434.

7. Hillocks,R.J.1984. Production of cotton varieties with resistance to Fusarium wilt with special reference to Tanzania. Tropical Pest Management 30:234246.

8. McFadden,H., D.Beasley, and C.L.Brubaker. 2004. Asseessment of Gossypium sturtianum and G.australe as potential sources of Fusarium wilt resistance to cotton. Euphytica 138:61-72.

9. Netzer, D.Y.Tal,A.Marani, and C.Weintall.1985.Resistance of interspecific Cotton hybrids (Gossypium hirsutum x G.barbadense containing G.harknessii cytoplasm) to Fusarium wilt. Plant Dis.69:312-313.

10. Osman,Eman, A.M.1996. Studies on the interrelationships among some Fusarium species with special reference to their pathogenecity On cotton. Ph.D.Thesis,. Cairo Univ., cairo,125pp.

11. Salgado, M.O.,H.F.Schwartz, and M.A.Pastor-Corrales.1994 Resistance To Fusarium oxysporum f.sp.phaseolin in tepary beans (phaseolus acutifolius) Plant Dis.78:357- 360.

12. Watkins,G.M.ed.1981.Copmpendium of Cotton Diseases. The American Phytopathological Society,St.Paul,MN..87P.

13. Zink, F.W., W.D.Guber, and R.G.Grogan.1983. Reaction of muskmelon germplasm to inoculation with Fusarium oxysporum f.sp. melonis race2.Plant Dis.67:1251-.1255. 


\section{تقييم مجموعة من الأصول الوراثية للقطن من حيث المقاومة لمرض

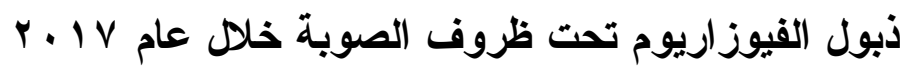

أمل عبد المنجي عسران ، محمود توفيق محمود منصور، محمد سبد خليل ، عبد الودود زكي عبد الله عاثور شوقي محمد المتولي زايد، ماريان منير حبيب و علي عبد الهادي علي

معهد بحوث امر اض النباتات ، مركز البحوث الزراعية ، الجيزة ، مصر

التراكيب الوراثية التي قيمت في الدراسة الحالية هي جزء من البرنامج القومي لتقيبم

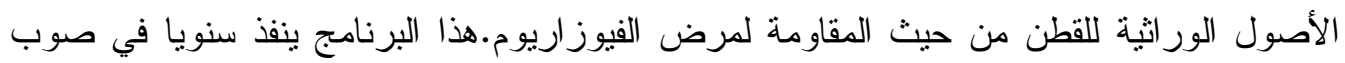

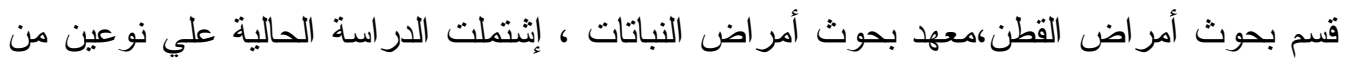

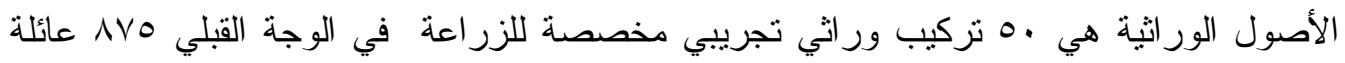
تتبع ستة اصناف تجارية. التزاكيب الور اثنة التجريبية أمكن الحصول عليها من قسم بحوث نربية نربية القطن، معهد بحوث القطن،أما عائلات الاصناف التجارية فقد أمكن الحصول عليها من قسم بحوث من لهن المحافظة علي أصناف القطن، معهد بحوث القطن. إستعملت النسب المئوية للبادر ات السليمة الباقية

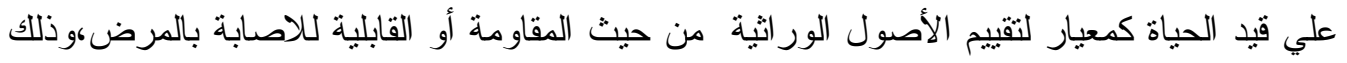

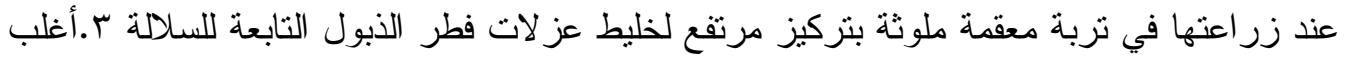

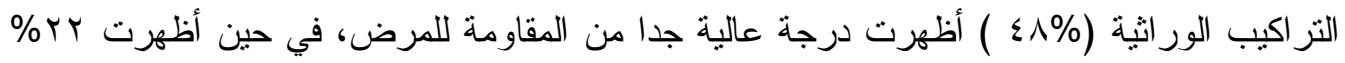

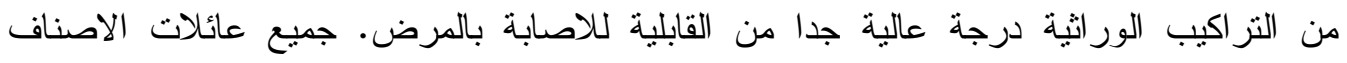

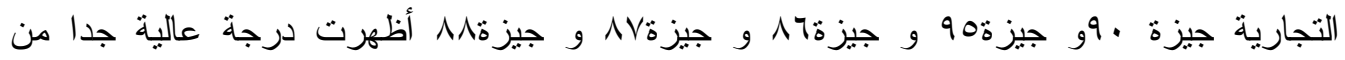

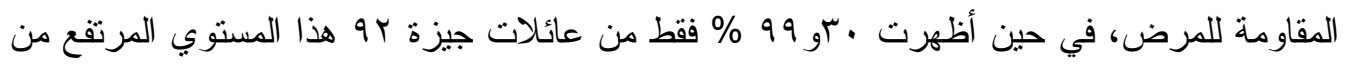

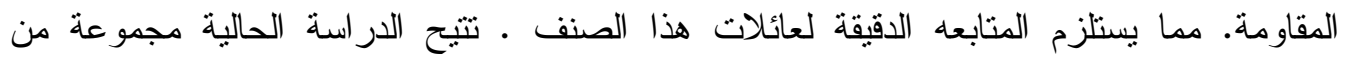
التر اكيب الور اثية المفيدة في مقاومة مرض ذبول الفيوزاريوم الناجم عن الاصابة بعزلات السلالة

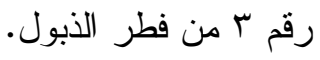


